\title{
The analysis of Betula pollen season in Poland in 2019
}

\author{
Krystyna Piotrowska-Weryszko', Elżbieta Weryszko-Chmielewska', Marta Dmitruk', Agnieszka Lipiec², \\ Małgorzata Malkiewicz ${ }^{3}$, Monika Ziemianin ${ }^{4}$, Katarzyna Dąbrowska-Zapart ${ }^{5}$, Alina Stacewicz ${ }^{6}$, \\ Adam Rapiejk0 ${ }^{7,8}$, Ewa Kalinowska ${ }^{7}$, Dariusz Jurkiewicz ${ }^{9}$, Grzegorz Siergiejko ${ }^{10}$, Piotr Rapiejko ${ }^{9}$ \\ ${ }^{1}$ Department of Botany and Plant Physiology, University of Life Sciences in Lublin, Poland \\ ${ }^{2}$ Department of Prevention of Environmental Hazards and Allergology, Medical University of Warsaw, Poland \\ ${ }^{3}$ Department of Palaeobotany, Institute of Geological Sciences, University of Wroclaw, Poland \\ ${ }^{4}$ Department of Clinical and Environmental Allergology, Medical College, Jagiellonian University, Cracow, Poland \\ ${ }^{5}$ Faculty of Natural Sciences, Institute of Earth Sciences, University of Silesia in Katowice, Poland \\ ${ }^{6}$ Institute of Marine \& Environmental Sciences, University of Szczecin, Poland \\ ${ }^{7}$ Allergen Research Center, Warsaw, Poland \\ ${ }^{8}$ Oxford Archaeology Ltd., Oxford, England \\ ${ }^{9}$ Department of Otolaryngology with Division of Cranio-Maxillo-Facial Surgery in Military Institute of Medicine, \\ Warsaw, Poland \\ ${ }^{10}$ Pediatrics, Gastroenterology and Allergology Department, University Children Hospital, \\ Medical University of Bialystok, Poland
}

\section{Abstract:}

The aim of this study was to compare Betula pollen seasons in 2019 in 12 cities located in different regions of Poland. Pollen monitoring was conducted in Bialystok, Bydgoszcz, Cracow, Lublin, Olsztyn, Opole, Piotrkow Trybunalski, Sosnowiec, Szczecin, Warsaw, Wroclaw, and Zielona Gora. Airborne pollen was monitored by the volumetric method using Burkard or Lanzoni pollen samplers. Pollen season length was determined by the $98 \%$ method. The pollen season start date was recorded earliest in Wroclaw and Zielona Gora, and latest in Bialystok. The highest Betula pollen concentration values were found in Lublin, whereas the lowest ones in Bialystok. In most of the cities, the maximum daily Betula pollen concentration was recorded on April 19 $9^{\text {th }}$ or $20^{\text {th }}$. Exceptionally, in Wroclaw the peak value occurred on April $8^{\text {th }}$, while in Bialystok as late as April $29^{\text {th }}$. The annual pollen sum reached the highest values in Warsaw and the lowest ones in Bialystok. The highest risk of allergy in people sensitive to the pollen of this taxon was found in Bydgoszcz, Zielona Gora, Szczecin, Opole, and Warsaw.

Key words: aeroallergens, pollen concentration, risk of allergy, birch, 2019

$\mathrm{T}$ he range of trees of the genus Betula is limited to the Northern Hemisphere where they are predominantly found in the temperate and cold zones. In Poland B. pendula and B. pubescens are the most common [1]. Betula pollen grains are recorded across almost the whole of Europe, from Scandinavia to central Spain and Italy. The highest pollen concentrations of this taxon are reported in the Boreal region, among others in Latvia, Finland, and Poland. The average seasonal pollen index (SPI) for Betula calculated based on data from several hundred pollen mon- itoring sites in Europe reached a value 32708 [2]. On the other hand, the total annual birch pollen sums, calculated as means from five years (2001-2005) for six Polish cities (Cracow, Lublin, Poznan, Szczecin, Sosnowiec, and Rzeszow) were 4665-14 551. The highest average values were recorded in Lublin, where during this period the maximum annual count was found in 2003 and it was 34134 pollen grains [3].

Betula pollen dispersion is most frequently considered at the regional scale of about 100 or $120 \mathrm{~km}$ $[4,5]$. However, we need to take into account the fact 
that only the fraction of emitted pollen remains as the ,regional component” [6]. Betula pollen grains are easily carried by air currents for large distances due to their small size, which is 19-22 $\mu \mathrm{m}$ [7]. Longrange transport of Betula pollen from East to West Europe and in the opposite direction has been recorded many times. Skjøth et al. [8] report about episodes of Betula pollen transport from Poland and Germany to Denmark. Pollen from Russia has been recorded in Finland [9], while pollen from Latvia, Sweden, Denmark, Belarus, Ukraine, Moldova, Germany, and Poland has been found in Lithuania [10].

Betula pollen allergens are one of the most common causes of pollen allergy in Poland [4]. Research demonstrates that in Poland $28 \%$ of patients exhibit sensitization to birch pollen [11]. Because it has been found that there is a linear statistically significant relationship between airborne pollen concentration and clinical allergy symptoms [12], it is very important to continually monitor the pollen content in the aerosol at many monitoring sites.

Aim

The aim of this study was to compare birch pollen seasons in 2019 in selected cities of Poland.

\section{Material and method}

In 2019 monitoring of airborne birch pollen was carried out in Bialystok, Bydgoszcz, Cracow,
Lublin, Olsztyn, Opole, Piotrkow Trybunalski, Sosnowiec, Szczecin, Warsaw, Wroclaw, and Zielona Gora. Airborne pollen concentrations were investigated by the volumetric method using Burkard or Lanzoni pollen samplers. Microscopic observations were performed on slides obtained in a 7-day cycle with assessment of 24-hour periods. Pollen concentrations were expressed as the number of pollen grains in $1 \mathrm{~m}^{3}$ of air per day $\left(\mathrm{P} / \mathrm{m}^{3}\right)$. Season start and end dates, maximum pollen concentrations, and annual pollen sums were determined. The length of birch pollen seasons was determined by the $98 \%$ method. The start and end of the season were defined as the date when $1 \%$ and $99 \%$ of the seasonal cumulative pollen count was trapped, respectively. The number of days on which the threshold values were recorded, at which the first allergy symptoms occur in people sensitized to birch pollen $\left(20 \mathrm{P} / \mathrm{m}^{3}\right)$ and symptoms in all allergic patients $\left(75 \mathrm{P} / \mathrm{m}^{3}\right)$ [13], was calculated for each of the cities. The study results are presented in graphs and shown in a table (figs 1-6, tab. 1).

\section{Results}

In most of the cities, the birch pollen season in 2019 started in the first or second week of April (tab. 1). The earliest pollen season start was recorded in Wroclaw and Zielona Gora (April $3^{\text {rd }}$ ), whereas the latest one in Bialystok (April 18 $8^{\text {th }}$ ). The end of the birch pollen season was observed between May $1^{\text {st }}$ and May $10^{\text {th }}$ (tab. 1). Maximum daily pollen concentra-

Table 1. Characteristics of Betula pollen season in 2019.

\begin{tabular}{|c|c|c|c|c|c|c|}
\hline \multirow{2}{*}{ Site } & \multirow{2}{*}{$\begin{array}{l}\text { Pollen season period } \\
\text { by the } 98 \% \text { method }\end{array}$} & \multirow{2}{*}{ Peak value $\left[\mathrm{P} / \mathrm{m}^{3}\right]$} & \multirow{2}{*}{ Peak date } & \multicolumn{2}{|c|}{ Days number with concentration above threshold } & \multirow{2}{*}{ Annual pollen sum } \\
\hline & & & & $20 \mathrm{P} / \mathrm{m}^{3}$ & $75 \mathrm{P} / \mathrm{m}^{3}$ & \\
\hline Bialystok & $18.04-10.05$ & 1033 & 29.04 & 20 & 15 & 7591 \\
\hline Bydgoszcz & $8.04-6.05$ & 2980 & 20.04 & 36 & 29 & 23538 \\
\hline Cracow & $5.04-1.05$ & 2911 & 20.04 & 27 & 21 & 17107 \\
\hline Lublin & $9.04-2.05$ & 6292 & 19.04 & 29 & 21 & 27727 \\
\hline Olsztyn & $9.04-6.05$ & 3198 & 20.04 & 30 & 23 & 23747 \\
\hline Opole & $4.04-1.05$ & 2897 & 19.04 & 30 & 26 & 21296 \\
\hline Piotrkow Trybunalski & $4.04-3.05$ & 3974 & 19.04 & 32 & 25 & 29596 \\
\hline Sosnowiec & $8.04-2.05$ & 1894 & 19.04 & 23 & 20 & 10460 \\
\hline Szczecin & $4.04-3.05$ & 1971 & 20.04 & 32 & 27 & 18139 \\
\hline Warsaw & $7.04-2.05$ & 4637 & 19.04 & 34 & 26 & 32163 \\
\hline Wroclaw & $3.04-1.05$ & 2923 & 8.04 & 30 & 25 & 22343 \\
\hline Zielona Gora & $3.04-1.05$ & 3268 & 19.04 & 34 & 27 & 27256 \\
\hline
\end{tabular}




\section{ORIEINAL PAPER}

Figure 1. Birch pollen concentration in Bialystok and Olsztyn in 2019.

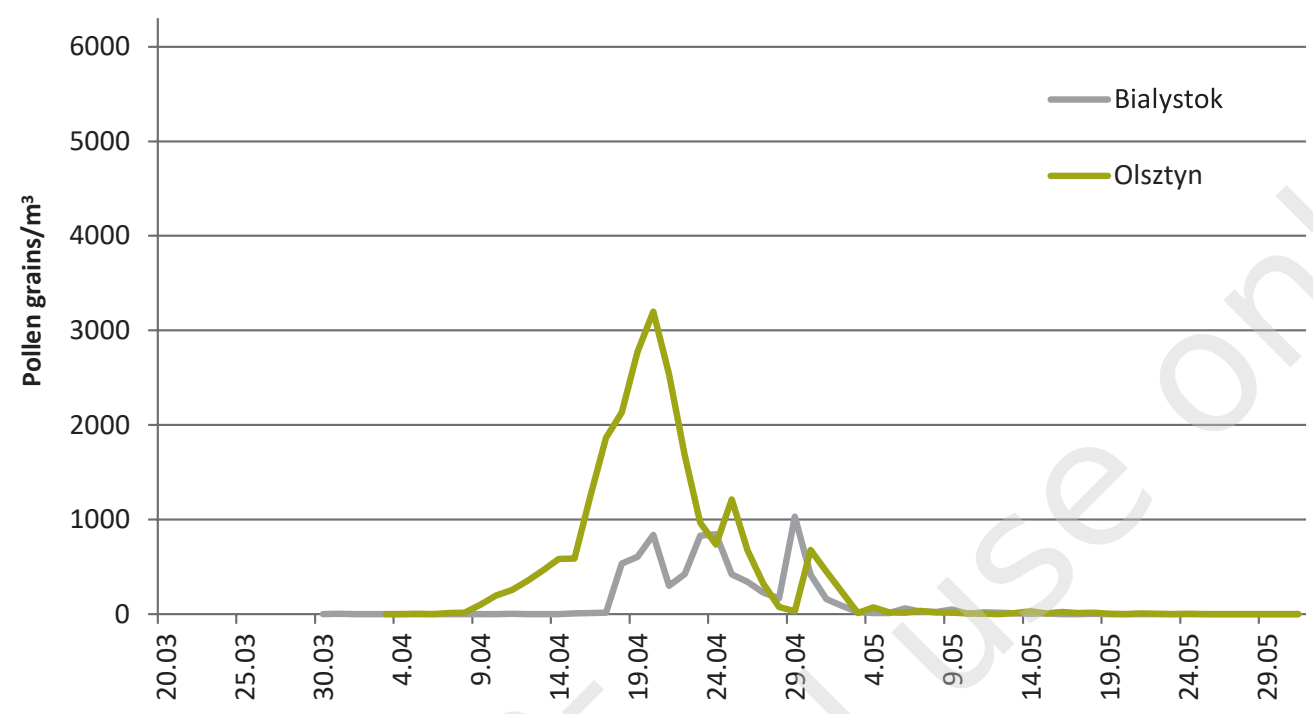

Figure 2. Birch pollen concentration in Cracow and Lublin in 2019.

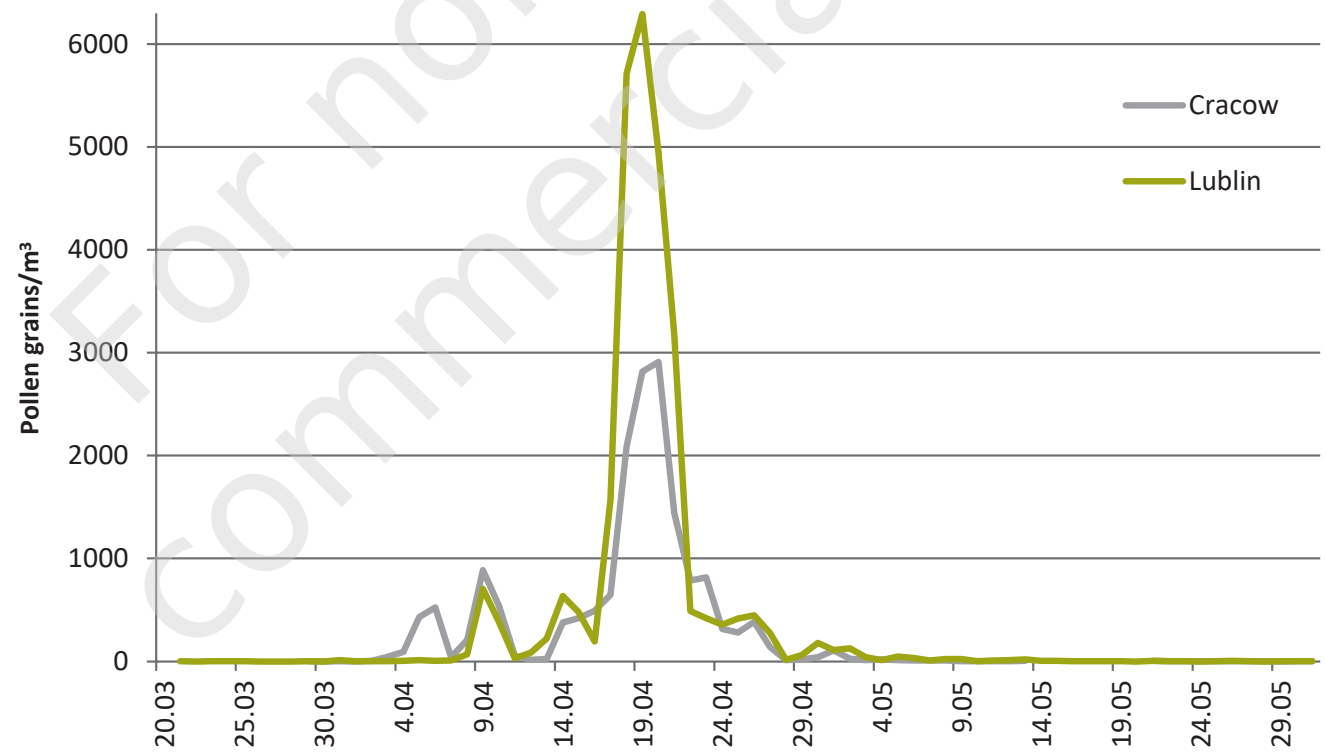

Figure 3. Birch pollen concentration in Piotrkow Trybunalski and Warsaw in 2019.

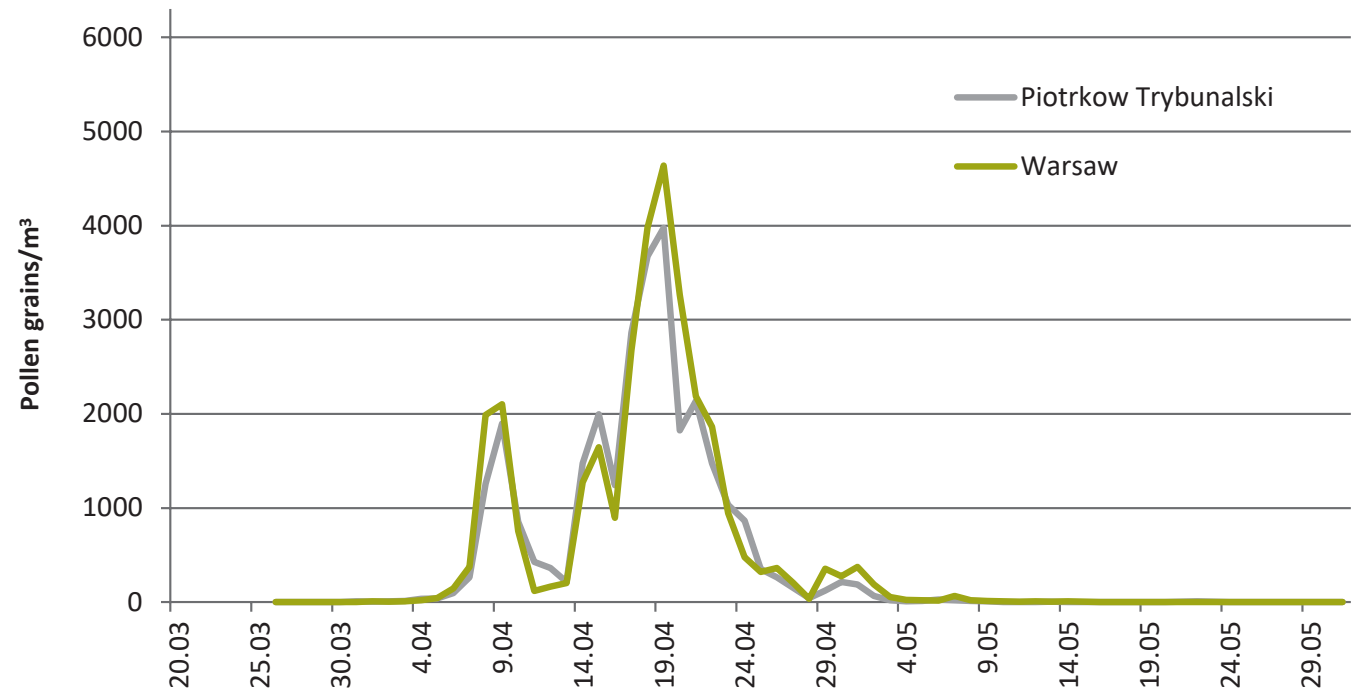


Figure 4. Birch pollen concentration in Bydgoszcz and Sosnowiec in 2019.

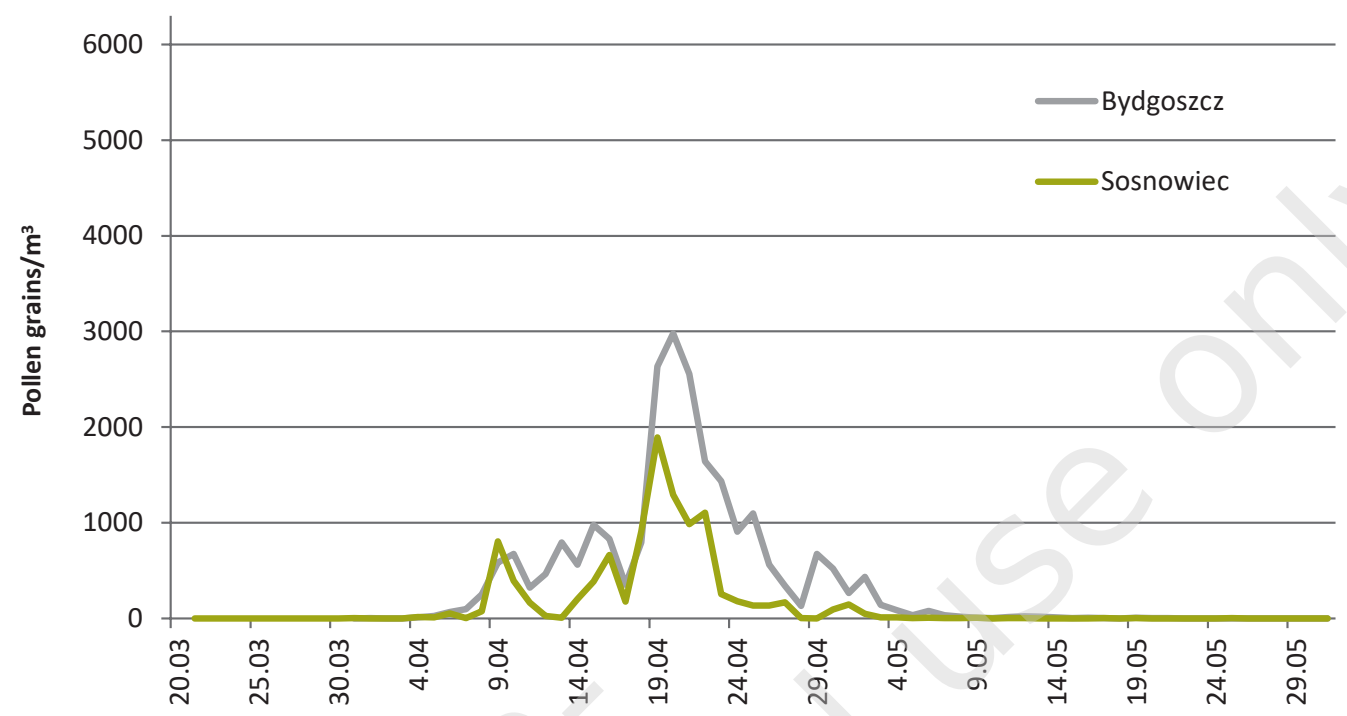

Figure 5. Birch pollen concentration in Opole and Zielona Gora in 2019.

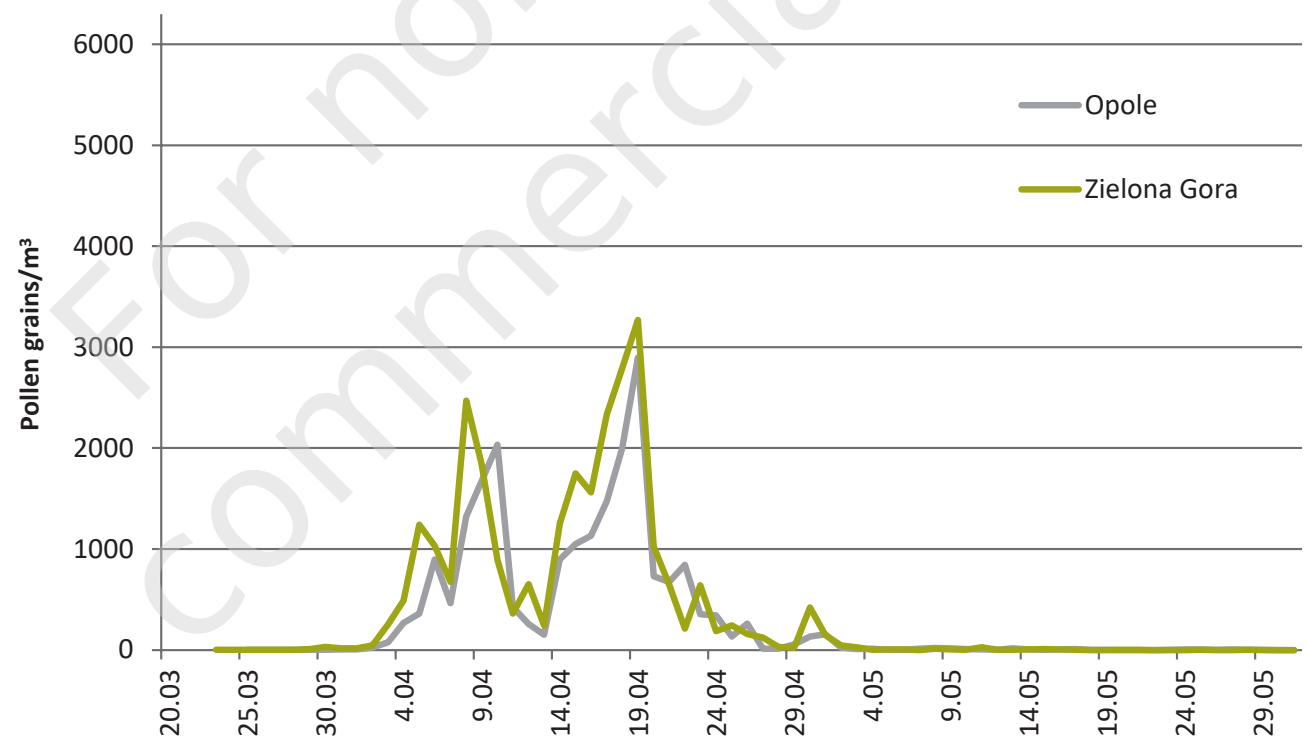

Figure 6. Birch pollen concentration in Szczecin and Wroclaw in 2019.

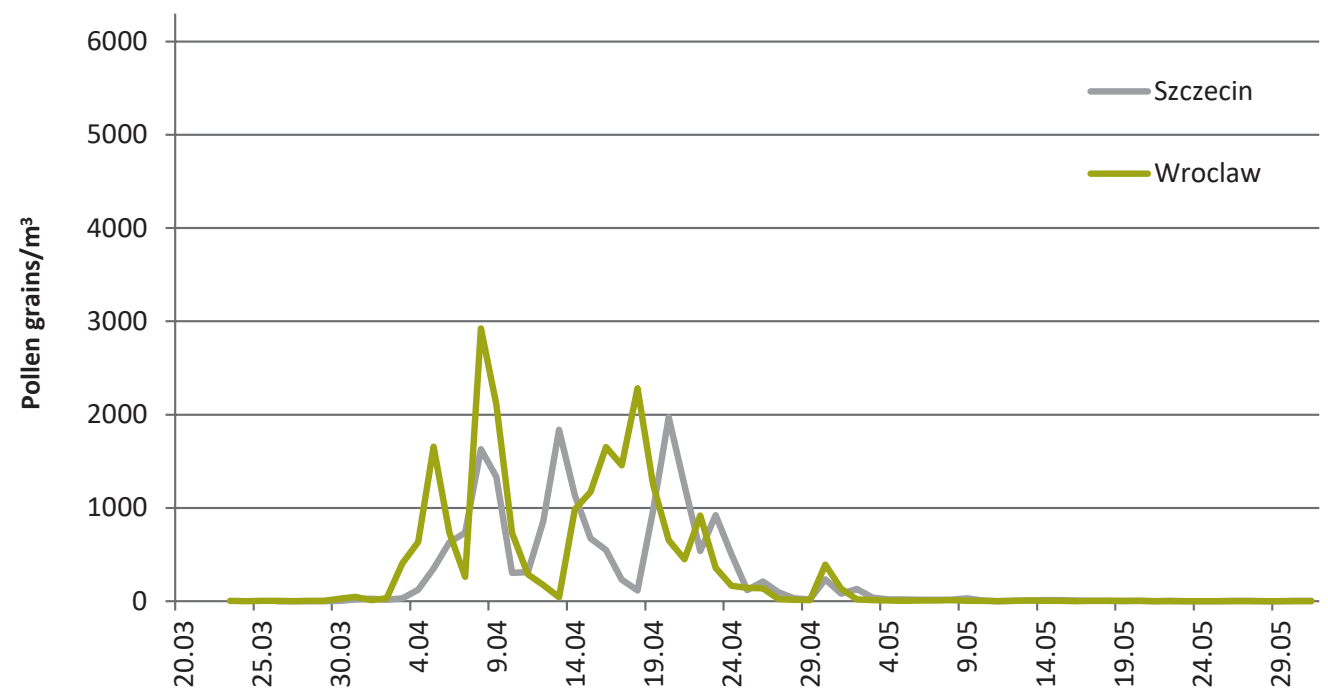


tions ranged between $1033 \mathrm{P} / \mathrm{m}^{3}$ and $6292 \mathrm{P} / \mathrm{m}^{3}$, with the highest ones recorded in Lublin and the lowest ones in Bialystok. Our study reveals that in most of the cities the dates of maximum pollen concentration occurred at a similar date, April $19^{\text {th }}$ or $20^{\text {th }}$ (tab. 1, figs 1-6). It was only in Wroclaw that the seasonal peak was observed on April $8^{\text {th }}$, while in Bialystok on April $29^{\text {th }}$. The risk of pollen allergy due to the persistence of pollen concentrations above $20 \mathrm{P} / \mathrm{m}^{3}$ was highest in Bydgoszcz (36 days), followed by Zielona Gora and Warsaw (34 days), Piotrkow Trybunalski and Szczecin (32 days). A very high pollen concentration of this taxon (above $75 \mathrm{P} / \mathrm{m}^{3}$ ) was recorded longest in Bydgoszcz (29 days), Zielona Gora and Szczecin (27 days), Opole and Warsaw (26 days). Pollen concentrations exceeding $75 \mathrm{P} / \mathrm{m}^{3}$ occurred earliest (since April $3^{\text {rd }}$ ) in the south-western part of Poland (Zielona Gora, Wroclaw, Opole), and then in Szczecin and Cracow (since April $4^{\text {th }}$ ). High airborne pollen concentrations were recorded latest in eastern Poland: in Bialystok (since April $18^{\text {th }}$ ) as well as in Lublin and Olsztyn (since April $9^{\text {th }}$ ). The annual birch pollen sum was highest in Warsaw (32 163 pollen grains), whereas it was lowest in Bialystok (7591 pollen grains). A relatively high pollen count was also recorded in Piotrkow Trybunalski (29 596 pollen grains), Lublin (27 727 pollen grains), and Zielona Gora (27 256 pollen grains).

\section{Discussion}

The presented data show that there was high spatial variability in the Betula annual pollen sum (7591-32 163) in Poland in 2019, which had also been found in the previous years [14-16]. In 2019 birch pollen abundance reached relatively high values at individual monitoring sites. This is evidenced by the average annual Betula pollen sums for the years 2016, 2017 [15, 17], and 2019 calculated for six cities (Cracow, Lublin, Opole, Sosnowiec, Wroclaw, Zielona Gora), which are respectively 22 502, 8080, and 21031.

Long-term research has produced results showing that Lublin is one of the cities where Betula pollen reaches the highest concentrations in Poland [3, 14]. The years 2016, 2014, and 2003 were particularly favorable for this taxon's pollen production in Lublin since the recorded annual counts were respectively 37 532, 34631 and 34134 [3, 17]. These values exceed the average pollen sum calculated for several hundred monitoring sites in Europe, which is 32708 [2].

On the other hand, the average annual Betula pollen sum calculated for Lublin based on the 20012014 study period was 15932 [14], which is a value almost twice lower than the annual birch pollen sum determined for this city in 2019 (27 727).

Wroclaw and Szczecin are the cities where the Betula pollen season started earliest in 2019 (April 3 $3^{\text {rd }}$ and April $4^{\text {th }}$, respectively). The average start dates of the birch pollen season in these cities calculated for the period 2001-2014 fell later, notably on April 10 ${ }^{\text {th }}$, but at the same time it was the earliest pollen season start date for this taxon among eight Poland's cities compared [14].

At most monitoring sites, the number of days with the birch pollen concentration exceeding $75 \mathrm{P} / \mathrm{m}^{3}$ ranged 20-29 in 2019, similarly as in the year 2016 which was also characterized by high birch pollen production and in which the number of such days was 23-28 [17].

\section{Conclusions}

In 2019 the birch pollen season started earliest in south-western Poland and latest in north-eastern Poland.

Pollen concentrations triggering allergic reactions in all pollen sensitive people occurred since April $3^{\text {rd }}-9^{\text {th }}$, while only in Bialystok since April $18^{\text {th }}$.

The highest peak values were observed in Lublin, similarly as in the previous years.

The greatest risk of Betula pollen allergy, associated with the largest number of days on which more than $75 \mathrm{P} / \mathrm{m}^{3}$ were recorded, was found in Bydgoszcz (29 days), Zielona Gora and Szczecin (27 days), Opole and Warsaw (26 days).

Birch pollen abundance in Poland in 2019 was at a relatively similar level to that recorded in 2016.

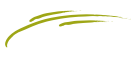

\section{References}

1. Szweykowska A, Szweykowski J (eds). Stownik botaniczny. Wiedza Powszechna, Warszawa 2003.

2. Skjøth CA, Sikoparija B, Jäger S, and EAN-Network. Pollen Sources. In: Sofiev M., KC Bergmann (eds). Allergenic Pollen: A Review of the Production, Release, Distribution and Health Impacts. Springer Dordrecht, Heidelberg, New York, London 2013: 9-27.

3. Weryszko-Chmielewska E (ed). Pytek roślin w aeroplanktonie różnych regionów Polski. (Pollen of plants in the aeroplankton of various regions of Poland). Wydawnictwo Akademii Medycznej w Lublinie, Lublin 2006.

4. Rapiejko P. Alergeny pytku roślin. Medical Education, Warszawa 2008 
5. Sofiev M, Belmonte J, Gehrig R et al. Airborne pollen transport. In: Sofiev M and Bergmann KC (eds). Allergenic Pollen: A Review of the Production, Release, Distribution and Health Impacts. Springer Dordrecht, Heidelberg, New York, London 2013: 127-160.

6. Faegri K, Iversen J, Krzywiński K. Textbook of pollen analysis. Wiley, Toronto 1989.

7. Weryszko-Chmielewska E (ed): Aerobiologia. Wydawnictwo Akademii Rolniczej w Lublinie, Lublin 2007.

8. Skjøth CA, Sommer J, Stach A et al. The long-range transport of birch (Betula) pollen from Poland and Germany causes significant pre-season concentrations in Denmark. Clinical and Experimental Allergy 2007, 37: 1204-1212.

9. Siljamo P, Sofiev M, Severova E et al. Sources, impact and exchange of early-spring birch pollen in the Moscow region and Finland. Aerobiologia 2008, 24: 211-230.

10. Veriankaitè L, Siljamo P, Sofiev M et al. Modelling analysis of source regions of long range transported birch pollen that influences allergenic seasons in Lithuania. Aerobiologia 2010, 26(1): 47-62.

11. Heinzerling LM, Burbach GJ, Edenharter $G$ et al. GA $L E N$ skin test study I: GA2LEN harmonization of skin prick testing: novel sensitization patterns for inhalant allergens in Europe. Allergy 2009, 64(10): 1498-1506.

12. Caillaud D, Martin S, Segala C et al. Effects of airborne birch pollen levels on clinical symptoms of seasonal allergic rhinoconjunctivitis. International Archives of Allergy and Immuno$\log$ 2014, 163(1): 43-50.

13. Rapiejko P, Lipiec A, Wojdas A et al. Threshold pollen concentration necessary to evoke allergic symptoms. Int Rev Allergol Clin 2004, 10(3): 91-93.
14. Puc M, Wolski T, Câmara Camacho I et al. Fluctuation of birch (Betula L.) pollen seasons in Poland. Acta Agrobot 2015, 68(4): 303-313.

15. Malkiewicz M, Lipiec A, Dąbrowska-Zapart $K$ et al. Birch pollen season in southern Poland in 2017. Alergoprofil 2017, 13(3): 118-123.

16. Lipiec A, Puc M, Siergiejko $G$ et al. The analysis of birch pollen season in northern Poland in 2017. Alergoprofil 2017, 13(4): 149-153.

17. Weryszko-Chmielewska E, Piotrowska-Weryszko K, Haratym W et al. Betula pollen season in southern Poland in 2016. Alergoprofil 2016, 12(2): 96-100.

K. Piotrowska-Weryszko - ID - orcid.org/ 0000-0003-3827-3218

E. Weryszko-Chmielewska - ID - orcid.org/0000-0001-8410-2757

M. Dmitruk - ID - orcid.org/0000-0001-9930-0633

A. Lipiec - ID - orcid.org/0000-0003-3037-2326

M. Malkiewicz - ID - orcid.org/0000-0001-6768-7968

M. Ziemianin - ID - orcid.org/ 0000-0003-4568-8710

K. Dąbrowska-Zapart - ID - orcid.org/ 0000-0002-8976-7739

A. Stacewicz - ID - orcid.org/0000-0002-3432-8536

E. Kalinowska - ID - orcid.org/ 0000-0003-4821-6882

P. Rapiejko - ID - orcid.org/ 0000-0003-3868-0294

Author's contributions: Piotrowska-Weryszko K: 40\%; other Authors: 5\% each. Conflict of interests: The authors declare that they have no competing interests. Ethics: The contents presented in this paper are compatible with the rules the Declaration of Helsinki, EU directives and standardized requirements for medical journals.

\section{Corresponding author:}

Krystyna Piotrowska-Weryszko, Assoc. Prof.

Department of Botany and Plant Physiology,

University of Life Sciences in Lublin

20-950 Lublin, Akademicka 15

e-mail: krystyna.piotrowska@up.lublin.pl 